\title{
Long-term air pollution exposure and cardio- respiratory mortality: a review
}

\author{
Gerard Hoek ${ }^{*}$, Ranjini M Krishnan², Rob Beelen ${ }^{1}$, Annette Peters ${ }^{3}$, Bart Ostro ${ }^{4}$, Bert Brunekreef ${ }^{1,5}$ \\ and Joel D Kaufman ${ }^{2}$
}

\begin{abstract}
Current day concentrations of ambient air pollution have been associated with a range of adverse health effects, particularly mortality and morbidity due to cardiovascular and respiratory diseases. In this review, we summarize the evidence from epidemiological studies on long-term exposure to fine and coarse particles, nitrogen dioxide $\left(\mathrm{NO}_{2}\right)$ and elemental carbon on mortality from all-causes, cardiovascular disease and respiratory disease. We also summarize the findings on potentially susceptible subgroups across studies. We identified studies through a search in the databases Medline and Scopus and previous reviews until January 2013 and performed a meta-analysis if more than five studies were available for the same exposure metric.

There is a significant number of new studies on long-term air pollution exposure, covering a wider geographic area, including Asia. These recent studies support associations found in previous cohort studies on PM2.5. The pooled effect estimate expressed as excess risk per $10 \mu \mathrm{g} / \mathrm{m}^{3}$ increase in $\mathrm{PM}_{2.5}$ exposure was $6 \%(95 \% \mathrm{Cl} 4,8 \%)$ for all-cause and $11 \%(95 \% \mathrm{Cl} 5,16 \%)$ for cardiovascular mortality. Long-term exposure to $\mathrm{PM}_{2.5}$ was more associated with mortality from cardiovascular disease (particularly ischemic heart disease) than from non-malignant respiratory diseases (pooled estimate 3\% $(95 \% \mathrm{Cl}-6,13 \%)$ ). Significant heterogeneity in $\mathrm{PM}_{2.5}$ effect estimates was found across studies, likely related to differences in particle composition, infiltration of particles indoors, population characteristics and methodological differences in exposure assessment and confounder control. All-cause mortality was significantly associated with elemental carbon (pooled estimate per $1 \mu \mathrm{g} / \mathrm{m}^{3} 6 \%(95 \% \mathrm{Cl} 5,7 \%)$ ) and $\mathrm{NO}_{2}$ (pooled estimate per $10 \mathrm{\mu g} / \mathrm{m}^{3} 5 \%(95 \% \mathrm{Cl} 3,8 \%)$ ), both markers of combustion sources. There was little evidence for an association between long term coarse particulate matter exposure and mortality, possibly due to the small number of studies and limitations in exposure assessment. Across studies, there was little evidence for a stronger association among women compared to men. In subjects with lower education and obese subjects a larger effect estimate for mortality related to fine PM was found, though the evidence for differences related to education has been weakened in more recent studies.
\end{abstract}

Keywords: Air pollution, Mortality, Motorized traffic, Cardiovascular, Respiratory, Particles

\section{Review}

\section{Background}

There is growing evidence of mortality effects related to long-term exposure (i.e., exposures of a year or more) to ambient air pollution [1-3]. Cardiovascular effects of short- and long-term exposure to particulate matter air pollution focusing on $\mathrm{PM}_{2.5}$ have recently been comprehensively reviewed $[4,5]$. Experimental and epidemiological

\footnotetext{
* Correspondence: g.hoek@uu.nl

${ }^{1}$ Institute of Risk Assessment Sciences, University of Utrecht, Utrecht, The Netherlands

Full list of author information is available at the end of the article
}

studies in the recent decade have significantly increased our knowledge of mechanisms that could plausibly explain the associations observed in epidemiological studies between ambient air pollution and mortality [4].

Most studies have reported associations linked to particulate matter, often represented by the mass concentration of particles smaller than $10 \mu \mathrm{m}\left(\mathrm{PM}_{10}\right)$ or $2.5 \mu \mathrm{m}$ $\left(\mathrm{PM}_{2.5}\right)$. In many urban areas, motorized traffic emissions are an important source of ambient particles and gaseous pollutants such as nitrogen oxides $\left(\mathrm{NO}_{2}\right.$ and $\mathrm{NO})$. Exposure contrasts related to traffic emissions are usually poorly represented by the concentration of $\mathrm{PM}_{10}$

\section{() Biomed Central}


or $\mathrm{PM}_{2.5}$, because of the high regional background concentration of these particle metrics from other sources $[6,7]$. However, there are more specific markers for traffic related air pollution, which include elemental carbon and ultrafine particles number [7-10]. Janssen and coworkers recently demonstrated that health impact assessments of traffic-related pollutants based upon $\mathrm{PM}_{2.5}$ seriously underestimated the health risks compared to an assessment based upon elemental carbon [7]. There is also growing evidence of health effects related to ultrafine particles $[8,9]$. Finally, the effects of coarse particles (the particle fraction between 2.5 and $10 \mu \mathrm{m}$ ) have attracted renewed attention [11]. Emission controls for road traffic have now substantially reduced tailpipe emissions, and therefore non-tailpipe emissions including engine crankcase emissions (combusted lubricating oil), road, tire and brake wear are becoming increasingly important. A recent study in the Netherlands found similar increases of concentrations in major roads compared to urban background for metals related to break and tire wear $(\mathrm{Cu}, \mathrm{Zn})$ as for soot and ultrafine particles which are due to tailpipe emissions [10] . In a review of the limited literature, coarse particles were associated with short-term effects on mortality and hospital admissions, but no evidence was found for long-term exposure effects [11]. The number of studies on long-term coarse particle exposure reviewed was small however at the time.

The aim of the current review is to evaluate the epidemiological evidence for cardiovascular and respiratory mortality effects of long-term exposure to fine particulate matter, including a meta-analysis. We focused on epidemiological studies of mortality, as experimental studies and mechanisms of effect have been discussed in detail previously [4]. The American Heart Association review [4] is updated with a significant number of new studies published in 2009 - 2012. We further include more pollutants in the review, specifically $\mathrm{NO}_{2}$, elemental carbon and coarse particles. We evaluated the findings on potentially susceptible subgroups across studies of $\mathrm{PM}_{2.5}$. In addition, we have included the studies on more specific cardiovascular causes of death, especially fatal myocardial infarction and stroke.

\section{Methods}

We performed a search in the databases Medline and Scopus with the search terms air pollution, cohort, and mortality until January 2013. We supplemented the search with studies included in the review by Brook and co-worker [4] and by browsing the reference lists of identified papers. In case more than five studies were identified, we performed a meta-analysis. We tested for heterogeneity of cohort-specific effect estimates and obtained combined effects estimates, using random effects methods of DerSimonian and
Laird [12]. The $\mathrm{I}^{2}$ statistic was calculated as a measure of the degree of heterogeneity across studies [13]. $\mathrm{I}^{2}$ ranges from 0 to $100 \%$ and can be interpreted as the variability of study-specific effect estimates attributable to true between study effects. From some studies multiple papers were available such as the Six Cities study [14-16]. In the meta-analysis we used only the most recent paper, which had longer follow-up. We only included studies in the quantitative meta-analysis that directly provided $\mathrm{PM}_{2.5}$ exposure estimates. For $\mathrm{NO}_{2}$ we only included studies which accounted for intra-urban spatial variation using e.g. dispersion models, land use regression models or spatial interpolation. We used STATA version 10 (Stata Corp, College Station, Texas) for metaanalysis. Effect estimates are presented as excess risks expressed per $10 \mu \mathrm{g} / \mathrm{m}^{3}$ contrast in exposure, except elemental carbon for which risks were expressed per $1 \mu \mathrm{g} / \mathrm{m}^{3}$.

\section{$P M_{2.5}$ and all-cause and cardiovascular mortality}

Table 1 and Figures 1 and 2 summarize the studies on long-term air pollution exposure and all-cause and cardiovascular mortality using $\mathrm{PM}_{2.5}$ or $\mathrm{PM}_{10}$ as exposure metric [14-39]. Most but not all studies report significant associations between $\mathrm{PM}_{2.5}$ and all-cause mortality. Since the publication of the authoritative American Heart Association Scientific Statement, sixteen new cohort studies were published between 2009 and January 2013. These studies were often performed in more selected groups e.g. female teachers $[27,36]$ or male truck drivers [32]. The geographic range has also been expanded significantly with several new studies from Japan and China now published. Another tendency is the publication of large studies based upon large population samples (e.g. census), with often less information on confounding variables such as individual smoking habits. Large cohort studies have used neighborhood socio-economic status and co-morbidities strongly associated with smoking as proxies for actual smoking data [26,38]. Effect estimates differed substantially across studies, with most studies showing less than $10 \%$ increase in mortality for an increment of $10 \mu \mathrm{g} / \mathrm{m}^{3} \mathrm{PM}_{2.5}$. The random effects summary estimate for the percent excess risk per $10 \mu \mathrm{g} / \mathrm{m}^{3} \mathrm{PM}_{2.5}$ for all-cause mortality was $6.2 \%$ (95\% CI: $4.1-8.4 \%$ ). A formal test of heterogeneity was statistically significant, with an $\mathrm{I}^{2}$ value of $65 \%$ indicating moderate heterogeneity. $\mathrm{I}^{2}$ can be interpreted as the variability in effect estimates due to true between study variability and not chance [13]. The random effects summary effect estimate for cardiovascular mortality was $10.6 \%$ (95\% CI 5.4, 16.0\%) per $10 \mu \mathrm{g} / \mathrm{m}^{3}$. Thus, the overall effect estimates were larger for cardiovascular than for all-cause mortality. This pattern was found in most of 
Table 1 Summary of effect estimates (excess risk per $10 \mu \mathrm{g} / \mathrm{m}^{3}$ ) from cohort studies on particulate matter $\left(\mathrm{PM}_{10}\right.$ or $\left.\mathrm{PM}_{2.5}\right)$ and mortality from all causes and cardiovascular diseases

\begin{tabular}{|c|c|c|c|c|c|c|c|c|}
\hline \multirow[t]{2}{*}{ Study } & \multirow[t]{2}{*}{ Study population } & \multirow[t]{2}{*}{ Follow-up period } & \multirow[t]{2}{*}{ Pollutant } & \multirow[t]{2}{*}{$\operatorname{Conc}^{a}\left(\mu \mathrm{g} / \mathrm{m}^{3}\right)$} & \multirow[t]{2}{*}{ Spatial scale ${ }^{b}$} & \multicolumn{2}{|c|}{$\begin{array}{l}\% \text { change in risk }(95 \% \mathrm{Cl}) \\
\text { in mortality associated with } \\
\text { a } 10 \mu \mathrm{g} / \mathrm{m}^{3} \text { increase PM }\end{array}$} & \multirow[t]{2}{*}{ References } \\
\hline & & & & & & All cause & Cardiovascular & \\
\hline Harvard six cities & 8111 adults in six US cities & $1976-1989$ & $\mathrm{PM}_{2.5}$ & $18(11-30)$ & City & $13(4,23)$ & $18(6,32)$ & [15] \\
\hline Harvard six cities & 8096 adults in six US cities & $1979-1998$ & $\mathrm{PM}_{2.5}$ & $15(10-22)$ & City & $16(7,26)$ & $28(13,44)$ & [14] \\
\hline Harvard six cities & 8096 adults in six US cities & $1974-2009$ & $\mathrm{PM}_{2.5}$ & $16(11-24)$ & City & $14(7,22)$ & $26(14,40)$ & [16] \\
\hline American Cancer Society (ACS) study & 552,800 adults from 51 US cities & $1982-1989$ & $\mathrm{PM}_{2.5}$ & $18(9-34)$ & City & $26(8,47)$ & NA & [17] \\
\hline ACS study & 500,000 adults from 51 US cities & $1982-1998$ & $\mathrm{PM}_{2.5}$ & $18(4)$ & City & $6(2,11)$ & $9(3,16)^{c}$ & [18] \\
\hline ACS sub-cohort study & 22,905 subjects in Los Angeles area & $1982-2000$ & $\mathrm{PM}_{2.5}$ & $(\sim 9-27)$ & Zip code (Int) & $17(5,30)$ & $26(1,60)^{c}$ & [19] \\
\hline German cohort & 4752 women in Ruhr area & $1985-2003$ & $\mathrm{PM}_{10}$ & $44(35-53)$ & Address (near) & $12(-9,37)$ & $52(8,114)$ & [20] \\
\hline German cohort & 4752 women in Ruhr and surrounding area & $1985-2008$ & $\mathrm{PM}_{10}$ & $44(35-53)$ & Address (near) & $22(6,41)$ & $61(26,104)$ & [21] \\
\hline $\begin{array}{l}\text { Women's Health Initiative } \\
\text { Observational Study }\end{array}$ & $\begin{array}{l}65,893 \text { postmenopausal women from } 36 \text { US } \\
\text { metropolitan areas }\end{array}$ & 1994-1998 & $\mathrm{PM}_{2.5}$ & $14(3-28)$ & Zip code (near) & NA & $76(25,147)$ & [22] \\
\hline Netherlands Cohort Study & 120, 852 subjects from Netherlands & $1987-1996$ & $\mathrm{PM}_{2.5}$ & $28(23-37)$ & Address (LUR) & $6(-3,16)$ & $4(-10,21)$ & [23] \\
\hline Nurses' Health Study & $\begin{array}{l}66,250 \text { women from the US north eastern } \\
\text { metropolitan areas }\end{array}$ & 1992-2002 & $\mathrm{PM}_{10}$ & $22(4)$ & Address (LUR) & $11(1,23)$ & $35(3,77)$ & [24] \\
\hline Nurses' Health Study & $\begin{array}{l}66,250 \text { women from the US north eastern } \\
\text { metropolitan areas }\end{array}$ & 1992-2002 & $\mathrm{PM}_{2.5}$ & $14(6-28)$ & Address (LUR) & $26(2,54)$ & NA & [25] \\
\hline Medicare national cohort & $\begin{array}{l}13.2 \text { million elderly Medicare recipients across } \\
\text { the USA }\end{array}$ & $2000-2005$ & $\mathrm{PM}_{2.5}$ & $13(4)$ & Zip code (Mean) & $4(3,6)^{d}$ & & [26] \\
\hline California teachers study & 45,000 female teachers & $2002-2007$ & $\mathrm{PM}_{2.5}$ & $18(7-39)$ & Address (near) & $6(-4,16)$ & $19(5,36)^{c}$ & [27] \\
\hline Swiss national cohort & National census data linked with mortality & $2000-2005$ & $\mathrm{PM}_{10}$ & $19(>40)^{e}$ & Address (Disp) & NA & $-1(-3,0)$ & [28] \\
\hline Health professionals follow-up study & $\begin{array}{l}17,545 \text { highly educated men in the midwestern } \\
\text { and northeastern US }\end{array}$ & $1989-2003$ & $\mathrm{PM}_{2.5}$ & $18(3)$ & Address (LUR) & $-14(-28,2)$ & $3(-17,26)$ & [29] \\
\hline Vancouver cohort & 452,735 Vancouver residents $45-85 \mathrm{yr}$ & $1999-2002$ & $\mathrm{PM}_{2.5}$ & $4(0-10)$ & Address (LUR) & NA & $7(-14,32)$ & [30] \\
\hline China nat. hypertension survey & 70,497 men and women & $1991-2000$ & TSP & $289(113-499)$ & City & $0.3(0,1)$ & $1(0,2)$ & [31] \\
\hline US trucking industry cohort & 53,814 men in the US trucking industry & $1985-2000$ & $\mathrm{PM}_{2.5}$ & $14(4)$ & Address (near) & $10(3,18)$ & $5(-7,19)$ & [32] \\
\hline Chinese retrospective cohort study & $\begin{array}{l}\text { 9,941 adults from five districts of Shenyang } \\
\text { city }\end{array}$ & $1998-2009$ & $\mathrm{PM}_{10}$ & $154(78-274)^{f}$ & District (mean) & $53(50,56)$ & $55(51,60)$ & [33] \\
\hline Canadian national cohort & 2.1 million nonimmigrant Canadians . $>25 \mathrm{yr}$ & $1991-2001$ & $\mathrm{PM}_{2.5}$ & $9(2-19)$ & $\begin{array}{l}\text { Enumeration area, } \\
\mathrm{N}=45710 \text { (satellite) }\end{array}$ & $10(5,15)$ & $15(7,24)$ & [34] \\
\hline New Zealand Census mortality study & 1.06 million adults in urban areas from 1996 & $1996-1999$ & $\mathrm{PM}_{10}$ & $8(0-19)$ & Census tract (Disp) & $7(3,10)$ & $6(1,11)$ & [35] \\
\hline
\end{tabular}


Table 1 Summary of effect estimates (excess risk per $10 \mu \mathrm{g} / \mathrm{m}^{3}$ ) from cohort studies on particulate matter $\left(P_{10}\right.$ or $\left.P M_{2.5}\right)$ and mortality from all causes and cardiovascular diseases (Continued)

\begin{tabular}{|c|c|c|c|c|c|c|c|c|}
\hline California teachers study & 101,784 female teachers & 1997- 2005 & $\mathrm{PM}_{2.5}$ & $16(3-28)$ & Address (Inter) & $1(-5,9)$ & $7(-5,19)$ & [36] \\
\hline Nippon data cohort & 7,250 adults $>30 \mathrm{yr}$ throughout Japan & $1980-2004$ & $\mathrm{PM}_{10}$ & $<27->43$ & District (near) & $-2(-8,4)$ & $-10(-19,0)$ & [37] \\
\hline Rome longitudinal study & $1,265,058$ adults from Rome & $2001-2010$ & $\mathrm{PM}_{2.5}$ & $23(7-32)$ & $\begin{array}{l}\text { Address } \\
\text { (DISP, } 1 \mathrm{~km} \text { grid) }\end{array}$ & $4(3,5)$ & $6(4,8)$ & [38] \\
\hline
\end{tabular}

${ }^{a}$ Mean with minimum - maximum in parentheses $\left(\mu \mathrm{g} / \mathrm{m}^{3}\right)$. One number in parentheses is standard deviation.

${ }^{\mathrm{b}}$ Spatial scale of exposure assignment, in parentheses exposure assignment method. City = average of monitors within the city; Near = nearest monitor concentration; LUR= land use regression; Disp= dispersion modeling; Inter = interpolation.

Cardio-pulmonary mortality reported if cardiovascular mortality not available.

${ }^{d}$ Combining the estimates from the three regions of the USA.

e Median and 90th percentile reported.

${ }^{f}$ Very high pollution levels that changed significantly during follow-up changing the ranking of the five districts.

Studies adjusted for individual smoking except references $[26,28,30,34,38,56]$. 


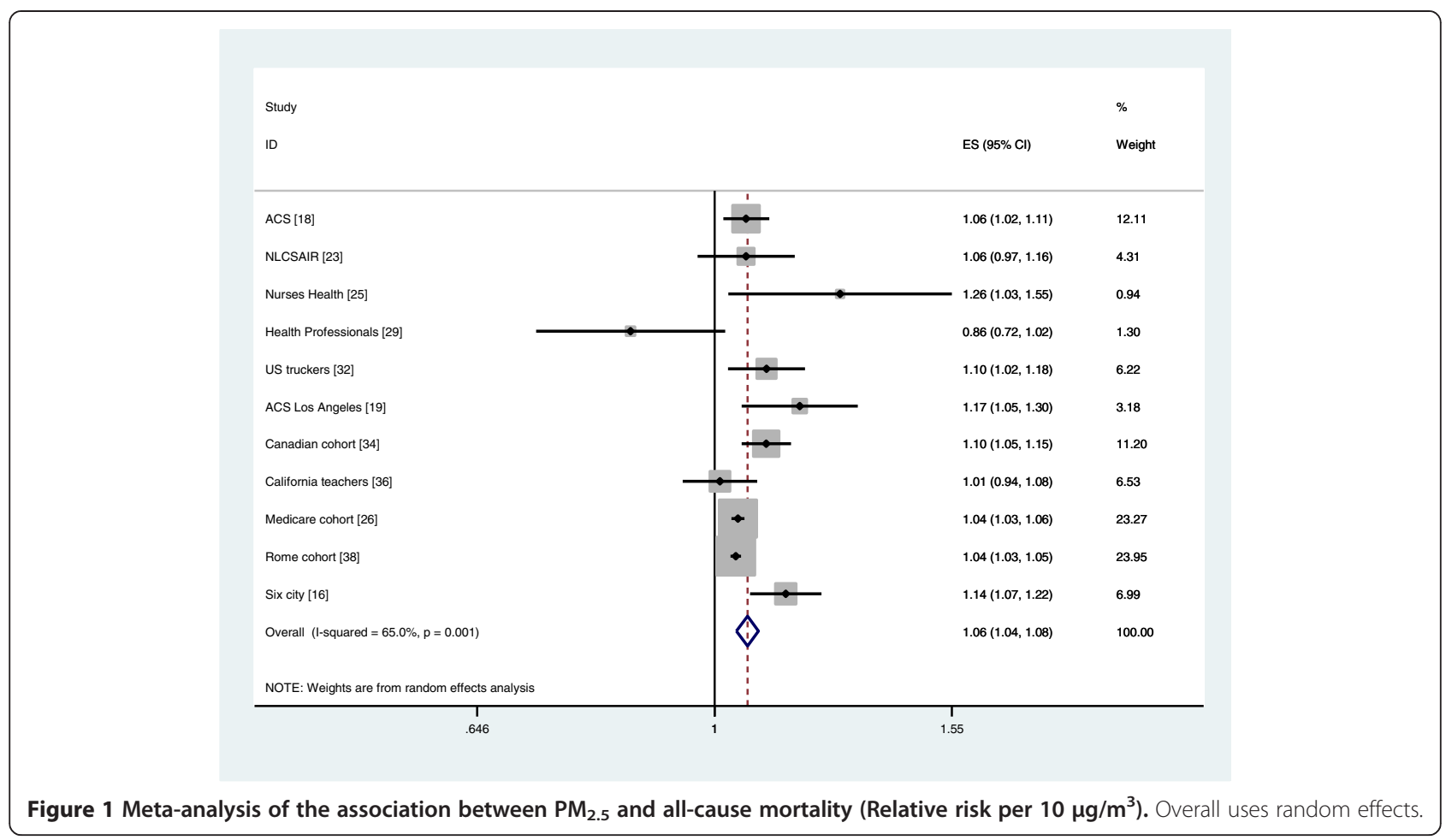

the individual studies, with the exceptions being the Dutch cohort study [23], the US trucking industry cohort study [32] and a national cohort study from New Zealand [35]. Significant and large heterogeneity of effects was found across studies, with an $\mathrm{I}^{2}$ statistic of 61\%. After excluding the Miller study [22], moderate heterogeneity remained $\left(\mathrm{I}^{2}=40 \%\right)$. Overall, the new studies have supported an association between $\mathrm{PM}_{2.5}$ and mortality first identified in the US Six City and ACS studies. It is of interest to note that the weight of the ACS study in the combined effect estimate is $12 \%$ for all-cause mortality, documenting that the combined estimate does not rely on one or two studies. Furthermore, effect estimates from the three large population cohorts without individual smoking data $[26,34,38]$ were not higher than those from the individual cohort studies. An important question is what the explanation is for the observed heterogeneity of effect estimates. Differences in study population, exposure assessment, pollution mixture, study period, outcome assessment, and confounder control could have contributed to these differences.

\section{Effect modification}

Differences in the fraction of susceptible subjects may have contributed to the observed differences. Brook [4] suggested that women might be more susceptible to ambient air pollution. The studies with higher PM effect estimates, particularly the WHI-study have indeed been performed in women only. However, it is problematic to draw conclusions about susceptible subgroups based upon between-study comparisons as multiple factors differ between studies. A comparison of PM effect estimates between men and women within studies does not provide clear evidence that women have a stronger response (Table 2). The findings from the AHSMOG are difficult to interpret, with higher effects in men in the larger earlier study [40] and larger effects in women in the smaller cohort with longer follow-up [41]. The larger effect estimate for BC for men in a Canadian study [30] has to be interpreted with care, because of the lack of data on a variety of important covariates, including individual smoking data, though the authors argue that smoking likely has not confounded the associations with mortality. In the French PAARC study, effect estimates for the evaluated pollutants (TSP, $\mathrm{BS}$ and $\mathrm{NO}_{2}$ ) were similar among men and women [42]. There is also only weak evidence that effect estimates are larger among never-smokers, though in all evaluated studies a (borderline) significant association was found in never-smokers (Table 2). Associations in current smokers were more variable across the studies, consistent with the larger 'noise' generated by smoking. In all four studies, $\mathrm{PM}_{2.5}$ effect estimates were higher for those with the lowest education and there was little indication of an association in those with higher education. The absence of an association in the (highly educated) Health professionals 


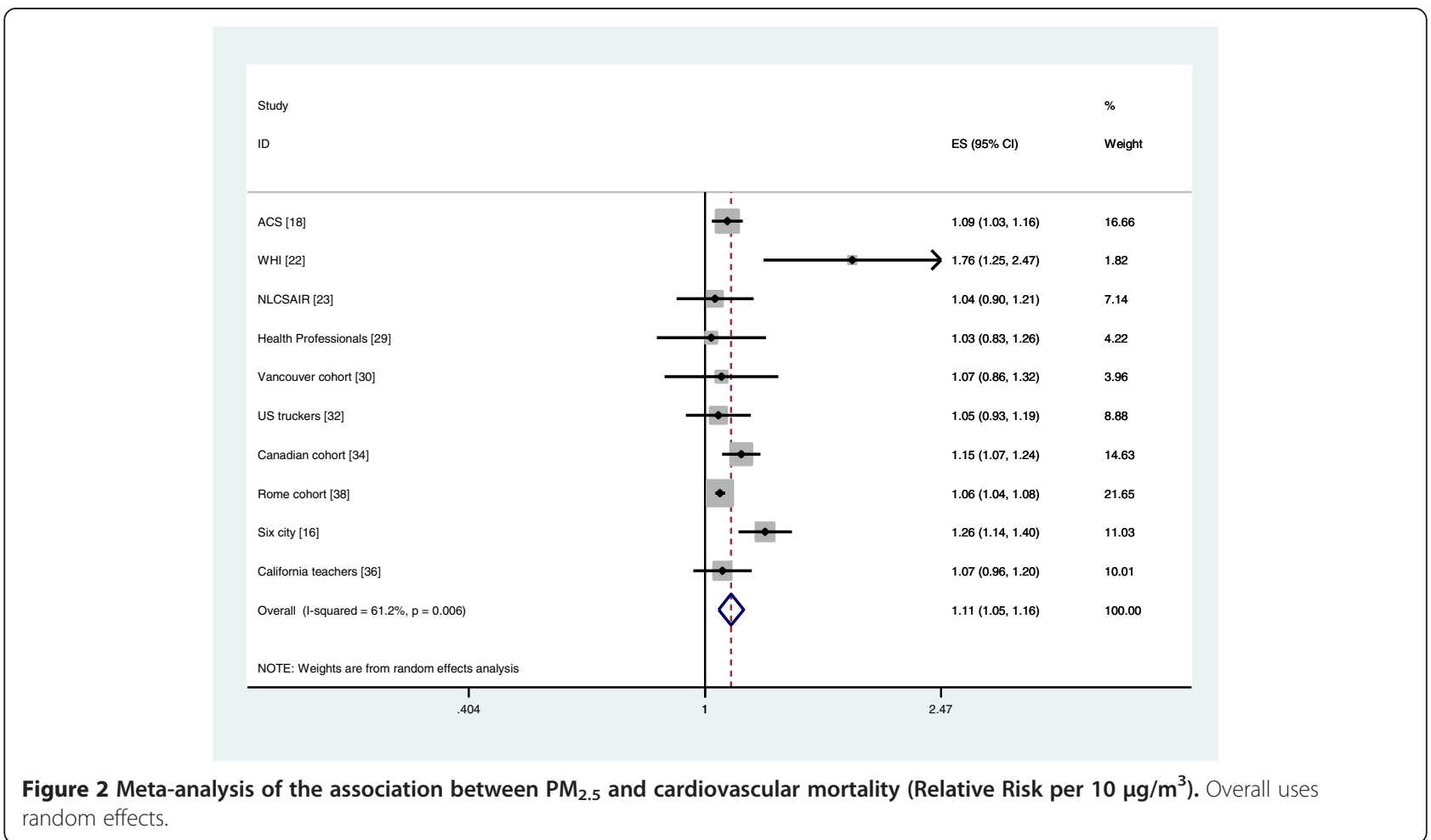

study [29] is consistent with this observation. In contrast, in the French PAARC study, effect estimates for Black Smoke were very similar across educational strata, with significant effect also found in those with a university degree [42]. Furthermore the $\mathrm{PM}_{2.5}$ effect estimates (excess risks) in an extended analysis of the ACS differed less than originally reported: $8.2 \%, 7.2$ and $5.5 \%$ per $10 \mu \mathrm{g} / \mathrm{m}^{3}$ for subjects with low, medium and high education respectively [43]. If confirmed in further studies, it is likely that multiple life style related factors may play a role in the stronger effects observed in less-educated subjects. These may include dietary factors such as lower fruit and antioxidant intake [23], higher risk of obesity or other preexisting diseases, higher actual exposures than assumed in the studies, lack of air conditioning and possibly interaction with other risk factors such as poorer housing conditions e.g. moisture.

In two studies, $\mathrm{PM}_{2.5}$ effect estimates were substantially higher among subjects with high body mass index $[22,24]$.

It is likely that subject characteristics might explain part of the variability of air pollution effect estimates across studies where subgroup analyses are limited by power to detect differences. Hence, further research is required to study the effects of air pollution on women, smokers, obese participants, and diabetes mellitus with better measurement of the exposures. Gene-environment interactions have been shown for the (short-term) air pollution effects on inflammation markers [44,45] Inflammation likely plays an important role in the mechanism of cardiovascular events [3,4]. Gene-environment interactions have not yet been studied in the framework of mortality cohort studies.

\section{Exposure issues}

One of the important sources of variability of effect estimates between studies is likely related to exposure definition and misclassification. While the most important environmental predictor to consider is actual individual-level exposure to ambient particles, which presumably drives the health effects, most studies have used outdoor concentrations at sites distant to the participant's precise location. The use of outdoor exposures leads to exposure misclassification. In the cohort studies, exposure has been characterized by the outdoor concentration at the city level based upon central site monitoring or the nearest monitor, or modeling at the individual address. Table 1 shows that the spatial scale of assessment and exposure assessment method varied significantly across studies, probably contributing to differences in effect estimates. Differences in pollution range across studies (Table 1) may have contributed as well. These exposure estimates do not take into account time activity patterns such as time spent in the home or in traffic and factors affecting infiltration of particles indoors. There is a large literature documenting the importance of air exchange rate on infiltration of particles indoors. Importantly, these factors may differ between homes within a study area and 
Table 2 Effect modification of the effect (excess risk per $10 \mu \mathrm{g} / \mathrm{m}^{3}$ ) of $\mathrm{PM}_{2.5}$ on cardiovascular mortality

\begin{tabular}{|c|c|c|c|c|c|c|c|}
\hline Subgroup & ACS $[18]^{a}$ & NLCS [23] & Harvard six city [43] & Nurses health [24] & WHI [22] & AHSMOG [40] & AHSMOG [41] \\
\hline \multicolumn{8}{|l|}{ Sex } \\
\hline Men & $5(0,11)$ & $3(-5,12)^{b}$ & $33(8,63)^{a}$ & NA & NA & $4(-3,11)$ & $-10(--24,5)$ \\
\hline Women & $6(0,12)$ & $7(0,14)$ & $20(-6,53)$ & & & $-3(-9,2)$ & $42(6,90)$ \\
\hline \multicolumn{8}{|c|}{ Smoking status } \\
\hline Never & $6(1,12)$ & $13(-4,32)$ & $36(2,82)$ & $83(20,179)$ & $18(-1,40)$ & NA & NA \\
\hline Former & $5(0,11)$ & $-4(-17,13)$ & $29(-3,72)$ & $22(-18,83)$ & $21(1,52)$ & & \\
\hline Current & $4(-2,11)$ & $3(-10,19)$ & $35(94,74)$ & $-12(-48,48)$ & $68(6,166)$ & & \\
\hline \multicolumn{8}{|l|}{ Education } \\
\hline Low & $11(6,18)$ & $20(-10,70)^{\mathrm{a}}$ & $45(13,85)$ & & $40(11,75)$ & NA & NA \\
\hline Medium & $6(1,13)$ & $2(-16,24)$ & $30(-2,73)$ & & $33(14,55)$ & & \\
\hline High & $1(-3,6)$ & $-10(-35,20)$ & $-3(-29,34)$ & & $11(-6,31)$ & & \\
\hline \multicolumn{8}{|c|}{ Body mass index } \\
\hline Non-Obese & NA & NA & NA & $8(-24,52)$ & $-1(-10,29)^{c}$ & NA & NA \\
\hline Obese & & & & $99(23,222)$ & $35(12,64)^{c}$ & & \\
\hline
\end{tabular}

${ }^{a}$ Read from graph.

b natural-cause mortality.

c for $\mathrm{BMI}<22.5$, continuous trend observed $\mathrm{NA}=$ not available.

between study areas in different climates. In a study of short-term effects, PM10 effects on hospital admissions were larger in US cities with lower\% of air conditioning, related to higher particle infiltration rates [46]. The impact of air conditioning use has not been investigated yet in the framework of cohort studies. In the Multiethnic study of Atherosclerosis Air study, indoor-outdoor measurements have been performed to adjust the exposure estimates $[47,48]$ and each participant provides time-activity information to weight exposures between time spent indoors and outdoors. Evidence for the importance of time activity patterns was obtained in the US truckers study, showing higher ambient $\mathrm{PM}_{2.5}$ effect estimates in the population excluding long-haul drivers who spend more time away from home [32]. Other factors could however also explain the higher effect estimated after excluding long-haul drivers. In the WHI study, effect estimates tended to be higher for subjects spending more than 30 minutes outdoors [22]. In a validation study in the Netherlands, the contrast of personal soot exposure for adults living on a major road compared to those living at a background location, was larger for those spending more time at home [49]. Because of the reliance on ambient exposure estimates, it is not surprising that some heterogeneity in effect estimates across studies is found.

Differences in particle composition or contributing sources very likely explain some of the heterogeneity in effect estimates, as was observed for short-term mortality and hospital admission studies of $\mathrm{PM}_{2.5}$ and $\mathrm{PM}_{10}$ [50-53]. For a comprehensive review we refer to the recent evaluation made by the World Health Organization (http://www.euro.who.int/en/what-we-do/health-topics/ environment-and-health/air-quality/publications/2013/ review-of-evidence-on-health-aspects-of-air-pollutionrevihaap). Particle composition effects have not been systematically investigated in cohort studies with the exception of the California teacher's study [27]. In a recent review it was shown that on a per microgram per $\mathrm{m}^{3}$ basis, mortality effect estimates were about 10 times larger for EC than for $\mathrm{PM}_{2.5}$ [7]. Hence, in locations with higher levels of primary combustion particles we could expect higher $\mathrm{PM}_{2.5}$ effects. In the next section, evidence on EC is further discussed.

A further important issue is for which period exposure is characterized. Air pollution data may not be available for the entire follow-up period. As an example in the ACS study, $\mathrm{PM}_{2.5}$ data were available at the start and end of follow-up [18]. When significant (often downward) trends in pollution occur with changing (often decreasing) spatial contrasts in the study, bias may occur in the estimated association between pollution and mortality. The follow-up study from the Harvard Six City study [14] and two studies in potentially at-risk populations $[54,55]$ suggested that the relevant exposure for cardiovascular effects may be the exposure in the past few years. These authors conclude that it does not take decades to bridge the gap between the short- and long-term exposure effect estimates, consistent with the effect of intervention studies showing reductions in mortality in the year after the intervention [54,55]. These studies [54,55] have made use of long-term temporal contrast within cities adjusting for secular trends. PM effect estimates were 
similar to the previously discussed studies exploiting spatial contrasts.

A further temporal issue in studies that use land use regression models for exposure assessment is that these models often are based upon current measurement campaigns and linked to health outcomes that occurred in the past. Three studies in the Netherlands, Rome (Italy) and Vancouver (Canada) have shown that for periods of about 10 years current LUR models predicted historic spatial contrasts well [56-58]. Even when concentrations have decreased over time, spatial contrasts often remain stable. Spatial contrasts may not be stable in areas with rapid economic development as indicated in one of the Chinese cohort studies in which the ranking of study areas changed during follow-up [33,59]. Even when the ranking of subjects is not changed, the quantitative spatial contrast in a study area may have changed, e.g. because the difference between major roads and background locations has decreased in time. Changed spatial contrasts will affect the estimated slope of the mortality pollution association $[18,56]$. Moving of subjects may further complicate the assessment.

An important question to address for the traffic pollution studies is potential confounding by road traffic noise, which has been shown to be related to cardiovascular disease including MI as well. A few studies have attempted to disentangle traffic-related air pollution and noise [60-62]. These studies found moderate correlations between air pollution and noise. The three studies differed somewhat in their findings of independent air pollution and noise effects. More work is needed in this area.

\section{Coarse particles and elemental carbon}

Table 3 presents studies that have used elemental carbon or coarse PM as the exposure metric. Table 3 illustrates that there is no evidence that long-term exposure to coarse PM is related to mortality. In three of the four cohort studies that reported no significant association with coarse PM, significant associations with $\mathrm{PM}_{2.5}$ were found $[18,25,63]$. However, exposure assessment for coarse particles is more challenging than for $\mathrm{PM}_{2.5}$ because of the influence of local sources, hence central site monitors are likely to have greater errors in representing residential concentrations. It is therefore possible that with more spatially resolved exposure assessment methods such as land use regression models or dispersion models, potential long-term exposure effects will be detected. The California Teacher's study did not evaluate coarse PM and did not find significant associations between all-cause mortality and elemental concentrations of $\mathrm{Si}, \mathrm{Fe}$ and $\mathrm{Zn}$, elements abundant in coarse particles, but did report an association between $\mathrm{Si}$ and ischemic heart disease [27].
Consistently, the summary estimate for $\mathrm{PM}_{10}$ was smaller than for $\mathrm{PM}_{2.5}$ with a summary effect estimate per $10 \mu \mathrm{g} / \mathrm{m}^{3}$ of $3.5 \%$ (95\% CI $0.4 \%, 6.6 \%$ ) with significant heterogeneity $\left(\mathrm{I}^{2}=69 \%\right)$ of the studies included in Table 1, excluding the because of changing spatial patterns difficult to interpret Chinese retrospective study [33]. The $\mathrm{PM}_{10}$ analysis was added as several studies only report $\mathrm{PM}_{10}$.

Effect estimates for EC were very consistent across studies [23,27,30,42,64-67]. The random effects summary estimate for all-cause mortality per $1 \mu \mathrm{g} / \mathrm{m}^{3}$ EC was $6.1 \%$ (95\% CI $4.9 \%, 7.3 \%$ ), with highly non-significant heterogeneity of effect estimates $\left(\mathrm{I}^{2}=0 \%\right)$. Most of the included studies assessed EC exposure at the cityscale $[27,64]$ which represents variation in city background but does not account for small-scale variation related to proximity to major roads. Many studies have documented significant intra-urban contrasts for EC, related to especially major roads [7]. Most likely EC and $\mathrm{NO}_{2}$ should be considered representatives of the complex mixture of traffic-related air pollution, rather than the only components causally associated with mortality.

There is fairly consistent evidence of associations of mortality with nitrogen dioxide (Table 4). The random effects summary estimate for all-cause mortality per $10 \mu \mathrm{g} / \mathrm{m}^{3}$ for $\mathrm{NO}_{2}$ was $5.5 \%$ (95\% CI 3.1\%, 8.0\%), with significant and large heterogeneity of effect estimates $\left(I^{2}=73 \%\right)$. In this analysis, the Chinese study [33] was not included as exposure was assessed at the district level. Inclusion of the essentially null findings of the ACS studyexcess risk of $0.3 \%$ (95\% CI $-0.8,1.3 \%$ )- resulted in an only slightly smaller combined estimate of $4.7 \%$ (95\% CI 2.4 , 7.1\%). In the ACS study, intra-urban variation was also not accounted for. As traffic-related air pollution varies on a small spatial scale, it is even more critical to assess exposure on a fine spatial scale such as the residential address than for $\mathrm{PM}_{2.5}$.

\section{Specific cardiovascular causes of death}

Table 5 shows associations between ambient air pollution and mortality from ischemic heart disease or myocardial infarction (MI), including studies based upon death certificates, more detailed studies using registry data, or ideally cohort studies with epidemiological review of medical records, allowing more precise identification of disease incidence. Several case-control studies based upon M.I. registries or epidemiological studies with clinical review have found associations between $\mathrm{NO}_{2}$ and fatal M.I. but not non-fatal M.I. [72-74]. Thus far, the finding of associations for fatal MI only was interpreted as an evidence that air pollution particularly affects the frail, or acts to aggravate a disease progression caused by other factors. On the other hand, it is also possible that the outcomes of ischemic heart diseases are misclassified and combined 
Table 3 Summary of effect estimates (excess risk per $10 \mu \mathrm{g} / \mathrm{m}^{3}$ ) from cohort studies on coarse particulate matter and elemental carbon $\left(\right.$ per $1 \mu \mathrm{g} / \mathrm{m}^{3}$ ) and mortality from all causes and cardiovascular diseases

\begin{tabular}{|c|c|c|c|c|c|c|c|c|}
\hline \multirow[t]{2}{*}{ Study name } & \multirow[t]{2}{*}{ Study design } & \multirow[t]{2}{*}{ Follow-up period } & \multirow[t]{2}{*}{ Pollutant } & \multirow[t]{2}{*}{$\operatorname{Conc}^{a}\left(\mu \mathrm{g} / \mathrm{m}^{3}\right)$} & \multirow[t]{2}{*}{ Spatial scale ${ }^{\mathbf{b}}$} & \multicolumn{2}{|c|}{$\begin{array}{l}\% \text { change in risk } \\
(95 \% \mathrm{Cl}) \text { in mortality }\end{array}$} & \multirow[t]{2}{*}{ References } \\
\hline & & & & & & All causes & Cardiovascular $^{c}$ & \\
\hline \multicolumn{9}{|l|}{ Coarse PM } \\
\hline ACS study & 500,000 adults 51 US cities & $1982-1998$ & $\mathrm{PM}_{2.5-15}$ & $19(6)$ & City & $1(-23)$ & $2(-2,5)^{*}$ & [18] \\
\hline AHSMOG study & 3769 California seventh-day Adventists & $1977-1992$ & $\mathrm{PM}_{2.5-15}$ & $27(4-44)$ & Address (Inter) & $5(-8,20)$ & NA & [63] \\
\hline Nurses' Health Study & $\begin{array}{l}66,250 \text { women from US north eastern } \\
\text { metropolitan areas }\end{array}$ & 1992- 2002 & $\mathrm{PM}_{2.5-10}$ & $8(0-27)$ & Address (LUR) & $3(-11,18)$ & NA & [25] \\
\hline $\begin{array}{l}\text { Health professionals } \\
\text { follow-up study }\end{array}$ & $\begin{array}{l}17,545 \text { highly educated men in the } \\
\text { midwestern and northeastern US }\end{array}$ & $1989-2003$ & $\mathrm{PM}_{2.5-10}$ & $10(3)$ & Address (LUR) & $-10(-22,4)$ & $8(-10,29)$ & [29] \\
\hline \multicolumn{9}{|l|}{ EC } \\
\hline Netherlands Cohort Study & 120, 852 subjects from Netherlands & $1987-1996$ & $\mathrm{BS}^{\mathrm{e}}$ & $17(9-36)$ & Address (LUR) & $5(0,11)$ & $4(-5,13)$ & [23] \\
\hline ACS study (extended) & 500,000 adults 51 US cities & $1982-1998$ & EC & $\mathrm{IQR}=0.31$ & City & $6(1,11)$ & $11(3,19)$ & [64] \\
\hline \multirow[t]{2}{*}{ Worcester Ml survivors } & 3,895 Ml patients & $1995-2005$ & EC & $0.4(0.1-0.9)$ & Address (LUR) & $2(-7,11)^{d}$ & NA & [65] \\
\hline & & & & & & $15(3,29)$ & & \\
\hline Vancouver cohort & 452,735 Vancouver residents $45-85 \mathrm{yr}$ & $1999-2002$ & BC & $1.5(0-5)$ & Address (LUR) & NA & $6(3,9)$ & [30] \\
\hline PAARC & 14,284 adults in 24 French areas & $1974-1998$ & BS & $44(18-77)$ & Address (near) & $7(3,10)$ & $5(-2,12)$ & [42] \\
\hline Veteran's study & 70,000 male US veterans & $1997-2001$ & EC & $0.6(0.1-2.0)$ & County (mean) & $18(5,33)$ & NA & [66] \\
\hline California teachers study & 45,000 female teachers & $2002-2007$ & EC & $1.1(0.2-2.4)$ & Address (near) & $3(-11,19)$ & $11(-9,36)$ & [27] \\
\hline Two Scotch cohorts & $\begin{array}{l}15,402 \text { and } 7,028 \text { adults from West-central } \\
\text { and central Scotland }\end{array}$ & $1972-19981970-1998$ & BS & 19 & LUR + temporal & $5(1,9)$ & $7(0,13)$ & [67] \\
\hline
\end{tabular}


Table 4 Summary of cohort studies on $\mathrm{NO}_{2}$ and mortality from all causes and cardiovascular diseases (excess risk per $10 \mu \mathrm{g} / \mathrm{m}^{3}$ )

\begin{tabular}{|c|c|c|c|c|c|c|c|c|}
\hline \multirow[t]{2}{*}{ Study name } & \multirow[t]{2}{*}{ Study population } & \multirow[t]{2}{*}{$\begin{array}{l}\text { Follow-up } \\
\text { period }\end{array}$} & \multirow[t]{2}{*}{ Pollutant } & \multirow[t]{2}{*}{$\operatorname{Conc}^{a}\left(\mu \mathrm{g} / \mathrm{m}^{3}\right)$} & \multirow[t]{2}{*}{ Spatial scale $^{\mathbf{b}}$} & \multicolumn{2}{|c|}{$\begin{array}{l}\% \text { change in risk }(95 \% \mathrm{Cl}) \\
\text { in mortality per } 10 \mu \mathrm{g} / \mathrm{m}^{3}\end{array}$} & \multirow[t]{2}{*}{ References } \\
\hline & & & & & & All causes & Cardiovascular & \\
\hline Oslo cohort & 16,209 men in Oslo, Norway & $1972-1998$ & $\mathrm{NO}_{x}$ & $11(1-168)$ & Address (DISP) & $8(6,11)$ & NA & [68] \\
\hline Netherlands Cohort Study & 120, 852 subjects from Netherlands & $1987-1996$ & $\mathrm{NO}_{2}$ & $37(15-67)$ & Address (LUR) & $8(0,16)$ & $7(-6,21)$ & [23] \\
\hline German cohort & 4752 women in Ruhr and surrounding area & $1985-2003$ & $\mathrm{NO}_{2}$ & $39(20-60)$ & Address (near) & $11(1,21)$ & $36(14,63)$ & [20] \\
\hline German cohort & 4752 women in Ruhr and surrounding area & $1985-2008$ & $\mathrm{NO}_{2}$ & $39(20-60)$ & Address (near) & $11(4,18)$ & $32(18,47)$ & [21] \\
\hline PAARC & 14,284 adults in 24 French areas & $1974-1998$ & $\mathrm{NO}_{2}$ & $20(12-32)$ & Address (near) & $14(3,25)$ & $27(4,56)$ & [42] \\
\hline China nat. hypertension survey & 70,497 men and women & $1991-2000$ & $\mathrm{NOx}$ & $50(20-122)$ & City & $2(0,3)$ & $2(1,4)$ & [31] \\
\hline Vancouver cohort & 452,735 Vancouver residents aged 45-85 yr & $1999-2002$ & $\mathrm{NO}_{2}$ & $32(15-58)$ & Address (LUR) & NA & $5(1,9)$ & [30] \\
\hline $\mathrm{DCH}$ & 52,061 adults in Copenhagen and Arhus & $1993-2009$ & $\mathrm{NO}_{2}$ & $17(11-60)$ & Address (DISP) & $8(2,13)$ & $15(3,27)$ & [69] \\
\hline US trucking industry cohort & 53,814 men in the US trucking industry & $1985-2000$ & $\mathrm{NO}_{2}$ & $28(14)$ & Address (LUR) & $5(3,7)$ & $4(0,8)$ & [32] \\
\hline Chinese retrospective cohort study & 9,941 adults from five districts of Shenyang city & $1998-2009$ & $\mathrm{NO}_{2}$ & $46(18-78)$ & District (mean) & $145(134,158)$ & $146(131,163)$ & [33] \\
\hline Rome longitudinal study & 684,000 adults from Rome & $2001-2006$ & $\mathrm{NO}_{2}$ & $45(11)$ & Address (LUR) & $4(3,5)$ & NA & {$[56]$} \\
\hline California Teachers study & 101,784 female teachers & $1997-2005$ & $\mathrm{NO}_{2}$ & $67(10-134)$ & Address (Inter) & $-3(-9,4)$ & $-2(-12,9)$ & [36] \\
\hline Shizuoka elderly cohort & 13,444 adults $>65 \mathrm{yr}$ & $1999-2006$ & $\mathrm{NO}_{2}$ & $25(-19,75)$ & Address (LUR) & $2(-4,8)$ & $15(3,28)$ & [70] \\
\hline Ontario tax cohort & 205, 440 adults in Toronto, Hamilton,Windsor & $1982-2004$ & $\mathrm{NO}_{2}$ & $43(8), 31(6), 24(5)^{c}$ & Address (LUR) & NA & $8(5,11)$ & [71] \\
\hline Rome longitudinal study & $1,265,058$ adults from Rome & $2001-2010$ & $\mathrm{NO}_{2}$ & $44(13-75)$ & Address (LUR) & $3(2,3)$ & $3(2,4)$ & [38] \\
\hline
\end{tabular}

${ }^{a}$ Mean with minimum - maximum in parentheses $\left(\mu \mathrm{g} / \mathrm{m}^{3}\right)$. One number in parentheses is standard deviation. Mean with minimum - maximum in parentheses $\left(\mu \mathrm{g} / \mathrm{m}^{3}\right)$. One number in parentheses is standard deviation.
b Spatial scale of exposure assignment, in parentheses exposure assignment method. City = average of monitors within the city; Near = nearest monitor concentration; LUR = land use regression; Disp = dispersion
modeling; Inter = interpolation.

c Mean (IQR) per city.

Studies adjusted for individual smoking except references $[26,28,30,34,38,56]$. 
Table 5 Summary of the studies on particulate matter and $\mathrm{NO}_{2}$ and mortality from specific cardiovascular diseases (excess risk per $10 \mu \mathrm{g} / \mathrm{m}^{3}$ )

\begin{tabular}{|c|c|c|c|c|c|c|c|}
\hline \multirow[t]{2}{*}{ Study name } & \multirow[t]{2}{*}{ Pollutant } & \multirow[t]{2}{*}{$\operatorname{Conc}^{a}\left(\mu g / m^{3}\right)$} & \multirow[t]{2}{*}{ Spatial scale ${ }^{\mathbf{b}}$} & \multicolumn{3}{|c|}{$\begin{array}{l}\% \text { change in risk }(95 \% \mathrm{Cl}) \text { in mortality } \\
\text { associated with a } 10 \mu \mathrm{g} / \mathrm{m}^{3} \text { increase }\end{array}$} & \multirow[t]{2}{*}{ References } \\
\hline & & & & IHD mortality & M.I mortality & Cerebrovascular mortality & \\
\hline ACS study & $\mathrm{PM}_{2.5}$ & $17(5)$ & City & $18(14,23)$ & NA & $2(-5,10)$ & [39] \\
\hline Oslo cohort & $\mathrm{NO}_{x}$ & $11(1-168)$ & Address (DISP) & $8(3,12)$ & NA & $4(-6,15)$ & [68] \\
\hline Women's Health Initiative Study & $\mathrm{PM}_{2.5}$ & $14(3-28)$ & Zip code 5 (near) & $76(25,147)$ & NA & NA & [22] \\
\hline Netherlands Cohort Study & BS & $17(9-36)$ & Address (LUR) & $1(-17,22)$ & NA & $39(-1,94)$ & [23] \\
\hline Nurses' Health Study & $\mathrm{PM}_{10}$ & $22(4)$ & Address (LUR) & $35(3,77)$ & NA & NA & [24] \\
\hline Nurses' Health Study & $\mathrm{PM}_{2.5}$ & $14(6-28)$ & Address (LUR) & NA & $102(7,278)$ & NA & [25] \\
\hline California teachers study & $\mathrm{PM}_{2.5}$ & $18(7-39)$ & Address (near) & $55(24,93)$ & NA & NA & [27] \\
\hline Swiss national cohort & $\mathrm{PM}_{10}$ & $19(>40)^{c}$ & Address (Disp) & $-1(-3,0)$ & NA & $-1(-2,0)$ & [28] \\
\hline Health professionals follow-up study & $\mathrm{PM}_{2.5}$ & $18(3)$ & Address (LUR) & $-2(-30,35)$ & NA & NA & [29] \\
\hline Canadian national cohort & $\mathrm{PM}_{2.5}$ & $9(2-19)$ & $\begin{array}{l}\text { Enumeration area, } \\
\mathrm{N}=45710 \text { (satellite) }\end{array}$ & $30(18,43)$ & NA & $4(-7,16)$ & [34] \\
\hline Californian Teachers study & $\mathrm{PM}_{2.5}$ & $16(3-28)$ & Address (Inter) & $20(2,41)$ & NA & $16(-8,46)$ & [36] \\
\hline Shizuoka elderly cohort & $\mathrm{NO}_{2}$ & $25(-19,75)$ & Address (LUR) & $27(2,58)$ & NA & $9(-6,27)$ & [70] \\
\hline Nippon data cohort & $\mathrm{PM}_{10}$ & $<27->43$ & District (near) & $-8(-27,17)$ & NA & $-14(-26,1)$ & [37] \\
\hline $\mathrm{DCH}$ & $\mathrm{NO}_{2}$ & $17(11-60)$ & Address (Disp) & $7(-9,26)$ & NA & $6(-14,32)$ & [69] \\
\hline Ontario Tax cohort & $\mathrm{NO}_{2}$ & $43(8), 31(6), 24(5)^{c}$ & Address (LUR) & $9(4,14)$ & NA & $-4(-10,5)$ & [71] \\
\hline Rome longitudinal study & $\mathrm{PM}_{2.5}$ & $23(7-32)$ & Address (DISP, 1 km grid) & $10(6,13)$ & NA & $8(4,13)$ & {$[38]$} \\
\hline \multicolumn{8}{|l|}{ M.I. registry studies } \\
\hline Stockholm & $\mathrm{NO}_{2}$ & $14(3-32)$ & Address (DISP) & NA & $15(-1,33)$ & NA & [72] \\
\hline Rome residents & $\mathrm{NO}_{2}$ & $(<30->60)$ & Census block (LUR) & NA & $7(2,12)$ & NA & [73] \\
\hline Stockholm residents & $\mathrm{NO}_{2}$ & $12(2-33)$ & Address (DISP) & NA & $8(5,11)$ & NA & [74] \\
\hline
\end{tabular}

$\mathrm{IHD}=$ ischemic heart disease; $\mathrm{MI}=$ myocardial infarction. Fatal $\mathrm{MI}$ reported for registry studies. $\mathrm{NA}=$ not available

${ }^{a}$ Mean with minimum - maximum in parentheses $\left(\mu \mathrm{g} / \mathrm{m}^{3}\right)$. One number in parentheses is standard deviation.

${ }^{\mathrm{b}}$ Spatial scale of exposure assignment, in parentheses exposure assignment method. City = average of monitors within the city; Near = nearest monitor concentration; LUR = land use regression; Disp = dispersion modeling; Inter = interpolation.

${ }^{\mathrm{C}}$ Median and 90th percentile reported.

Studies adjusted for individual smoking except references $[26,28,30,34,38,56]$ 
as composite outcomes, where fatal outcomes are captured more precisely [75]. Although there is increasing evidence that air pollution is associated with markers of early atherosclerosis, it is possible that air pollution will affect the underlying biological processes that predispose to atherothrombosis (which leads to MI and stroke) compared to atherosclerosis [76,77]. Another explanation is that the type of outcomes affected by pollution are those that have higher case-fatality rates (e.g., arrhythmic sudden death has higher case-fatality rate than overall MI).

Fewer studies have evaluated cerebrovascular mortality. In the Dutch cohort study and in the Women's Health Initiative Study, a strong association was found [22,23]. In contrast, in the ACS study, the Norwegian cohort, and the Swiss national cohort study no association was found $[28,39,68]$. It is possible that poorer recording of cerebrovascular mortality on death certificates has contributed to these inconsistencies. There is also some evidence from ecological studies that air pollution may contribute to stroke mortality $[78,79]$.

Two studies have reported significant associations between particulate matter air pollution and dysrhythmia, heart failure and cardiac arrest combined $[39,60]$. These results are based upon smaller numbers of events, and require large cohort studies for further verification. The results are consistent with several studies documenting significant associations between short-term $\mathrm{PM}$ or $\mathrm{NO}_{2}$ exposure and mortality due to heart failure and dysrhythmia and defibrillator discharges $[4,80]$.

\section{Air pollution and respiratory mortality}

Table 6 shows the effect estimates for respiratory mortality. In the two first US cohort studies, no association between $\mathrm{PM}_{2.5}$ and respiratory mortality was found [15,17]. In contrast to the findings of these US studies, strong associations were found in the Dutch cohort study [23], a Norwegian study [68] and a Chinese study [59]. The random effect pooled estimate per $10 \mu \mathrm{g} / \mathrm{m}^{3}$ for $\mathrm{PM}_{2.5}$ was $2.9 \%(95 \% \mathrm{CI}-5.9,12.6 \%)$, highly non-significant. The heterogeneity across studies was statistically significant with an $\mathrm{I}^{2}$ statistic of $59 \%$, indicating moderate heterogeneity. Associations for PM were weaker in the Dutch and Chinese cohort study than with $\mathrm{NO}_{2}$ or $\mathrm{NO}_{\mathrm{x}}$. Respiratory mortality may be more related to primary traffic-related pollutants than with long-range transported particles, though further work is needed to test this hypothesis. The smaller number of deaths due to respiratory disease compared to cardiovascular diseases, contributed to larger confidence intervals within individual studies and larger variability of the main effect estimates across studies. In time series studies including several large multi-city studies in the

Table 6 Summary of the studies on air pollution and mortality from all respiratory disease (excess risk per $10 \mu \mathrm{g} / \mathrm{m}^{3}$ )

\begin{tabular}{|c|c|c|c|c|c|}
\hline Study Name & Pollutant & $\operatorname{Conc}^{a}\left(\mu \mathrm{g} / \mathrm{m}^{3}\right)$ & Spatial scale & $\begin{array}{l}\% \text { change in risk }(95 \% \mathrm{Cl}) \\
\text { in mortality per } 10 \mu \mathrm{g} / \mathrm{m}^{3}\end{array}$ & References \\
\hline AHSMOG & $\mathrm{PM}_{10}$ & $51(17)$ & Address (Inter) & $6(-1,15)$ & {$[40]$} \\
\hline ACS study & $\mathrm{PM}_{2.5}$ & $17(5)$ & City & $-8(-14,-2)$ & [39] \\
\hline Oslo cohort & $\mathrm{NO}_{x}$ & $11(1-168)$ & Address (DISP) & $16(6,26)$ & {$[68]$} \\
\hline Harvard six cities & $\mathrm{PM}_{2.5}$ & $15(10-22)$ & City & $8(-21,49)$ & {$[14]$} \\
\hline Netherlands Cohort Study & $\mathrm{PM}_{2.5}$ & $28(23-37)$ & Address (LUR) & $7(-25,52)$ & {$[23]$} \\
\hline Netherlands Cohort Study & $\mathrm{NO}_{2}$ & $37(15-67)$ & Address (LUR) & $12(0,26)$ & [23] \\
\hline California Teachers study & $\mathrm{PM}_{2.5}$ & $18(7-39)$ & Address (near) & $3(-20,34)$ & {$[27]$} \\
\hline China national. hypertension survey & $\mathrm{NO}_{x}$ & $50(20-122)$ & City & $3(0,6)$ & {$[31]$} \\
\hline China national. hypertension survey & $\mathrm{TSP}$ & $289(113-499)$ & City & $0.3(-1,1)$ & {$[31]$} \\
\hline US truckers study & $\mathrm{PM}_{2.5}$ & $14(4)$ & Address (near) & $20(-9,60)$ & [32] \\
\hline US truckers study & $\mathrm{NO}_{2}$ & $28(14)$ & Address (LUR) & $15(1,31)$ & {$[32]$} \\
\hline California Teachers study & $\mathrm{PM}_{2.5}$ & $16(3-28)$ & Address (Inter) & $21(-3,52)$ & {$[36]$} \\
\hline New Zealand Census study & $\mathrm{PM}_{10}$ & $8(0-19)$ & Census tract (Disp) & $14(5,23)$ & {$[35]$} \\
\hline Shenyang cohort study & $\mathrm{PM}_{10}$ & $154(78-274)$ & District (mean) & $67(60,74)$ & {$[59]$} \\
\hline Shenyang cohort study & $\mathrm{NO}_{2}$ & $46(18-78)$ & District (mean) & $197(169,227)$ & [59] \\
\hline Shizuoka elderly cohort & $\mathrm{NO}_{2}$ & $25(-19,75)$ & Address (LUR) & $19(2,38)$ & {$[70]$} \\
\hline Two Scotch cohorts & BS & 19 & LUR + temporal & $11(-3,28)$ & {$[67]$} \\
\hline Rome longitudinal study & $\mathrm{PM}_{2.5}$ & $23(7-32)$ & Address (DISP, 1 km grid) & $3(-3,8)$ & [38] \\
\hline
\end{tabular}

${ }^{a}$ Mean with minimum - maximum in parentheses $\left(\mu \mathrm{g} / \mathrm{m}^{3}\right)$. One number in parentheses is standard deviation.

${ }^{b}$ Spatial scale of exposure assignment, in parentheses exposure assignment method. City = average of monitors within the city; Near = nearest monitor concentration; LUR = land use regression; Disp = dispersion modeling; Inter = interpolation

Studies adjusted for individual smoking except references $[26,28,30,34,38,56]$. 
USA and Europe, significant associations between daily variations in PM and respiratory mortality were found [1-4]. Expressed per $10 \mu \mathrm{g} / \mathrm{m}^{3}$ PM excess risks of about $1 \%$ are typically reported for short-term exposures, larger than for all-cause mortality [1-4]. In contrast to cardiovascular disease, current evidence therefore does not suggest an additional risk from long-term exposure, possibly related to mortality displacement $[2,3]$. More studies are needed to evaluate long-term exposures on respiratory mortality more thoroughly.

\section{Conclusions}

There is a significant number of new studies on longterm air pollution exposure, covering a wider geographic area, including Asia. These recent studies support associations found in previous cohort studies on $\mathrm{PM}_{2.5}$. The pooled effect estimate expressed as excess risk per $10 \mu \mathrm{g} / \mathrm{m}^{3}$ increase in $\mathrm{PM}_{2.5}$ exposure was $6 \%$ (95\% CI 4 , $8 \%)$ for all-cause and $11 \%(95 \% 5,16 \%)$ for cardiovascular mortality. Long-term exposure to $\mathrm{PM}_{2.5}$ was more associated with mortality from cardiovascular disease (particularly ischemic heart disease) than from nonmalignant respiratory diseases (pooled estimate 3\% (95\% CI $-6,13 \%)$ ). Significant heterogeneity in $\mathrm{PM}_{2.5}$ effect estimates was found across studies, likely related to differences in particle composition, infiltration of particles indoors, population characteristics and methodological differences in exposure assessment and confounder control. All-cause mortality was significantly associated with elemental carbon (pooled estimate per $1 \mu \mathrm{g} / \mathrm{m}^{3}$ 6\% (95\% CI 5, 7\%)) and $\mathrm{NO}_{2}$ (pooled estimate per $10 \mu \mathrm{g} / \mathrm{m}^{3} 5 \%$ (95\% CI 3, 8\%)), both markers of combustion sources. There was little evidence for an association between long term coarse particulate matter exposure and mortality, possibly due to the small number of studies and limitations in exposure assessment. Across studies, there was little evidence for stronger association among women compared to men. Subjects with lower education and obese subjects experienced larger mortality effect related to fine PM, though the evidence for differences related to education has been weakened in more recent studies.

Our review suggests several specific research questions. Research into the reasons for the heterogeneity of effect estimates would be extremely useful for health impact assessment. Better exposure assessment including spatially resolved outdoor exposures and more chemically speciated PM might in part be able to resolve the observed heterogeneity. Chemical speciation would allow assessing particles from different sources e.g. particles from combustion sources and non-tailpipe emissions separately, a question clearly relevant for air pollution control policy. Specific attention to motorized traffic emissions is important because (road) traffic is an important source of ambient air pollution. More work on coarse particles and at the other side of the particle size spectrum, ultrafine particles is needed. Ongoing new research in the USA in the Multi-Ethnic study of Atherosclerosis and Air pollution (MESA-AIR) and the European Study of Cohorts for Air Pollution Effects (ESCAPE) that use large cohorts and state-of the art spatially-resolved exposure methods will likely contribute significant new answers in the near future to these questions.

\section{Abbreviations \\ ACS: American Cancer Society study; BS: Black Smoke; BC: Black Carbon; $\mathrm{Cl}$ : Confidence interval; EC: Elemental Carbon; $\mathrm{NO}_{2}$ : Nitrogen dioxide; $\mathrm{NO}_{\mathrm{x}}$ : Nitrogen oxides; $\mathrm{PM}$ : Particulate matter; $\mathrm{PM}_{2.5}$ : Particles smaller than $2.5 \mu \mathrm{m} ; \mathrm{PM}_{10}$ : Particles smaller than $10 \mu \mathrm{m} ; \mathrm{TSP}$ : Total suspended particles.}

\section{Competing interests}

None of the authors has a competing interest.

\section{Authors' contributions}

$\mathrm{GH}, \mathrm{RMK}, \mathrm{RB}, \mathrm{AP}, \mathrm{BO}, \mathrm{BB}$ and JK have contributed to the definition of the scope of the review, identification of studies and interpretation of results. $\mathrm{GH}$ drafted the text. GH, RMK, RB, AP, BO, BB and JK provided critical comments and approved the final manuscript.

\section{Acknowledgments}

The paper has been prepared in the framework of the projects ESCAPE and TRANSPHORM. The research leading to these results has received funding from the European Community's Seventh Framework Program (FP7/20072011) under grant agreement number: 211250 .

\section{Author details}

${ }^{1}$ Institute of Risk Assessment Sciences, University of Utrecht, Utrecht, The Netherlands. ${ }^{2}$ University of Washington, Seattle, WA, USA. ${ }^{3}$ Institute of Epidemiology II, Helmholtz Zentrum München -German Research Center for Environmental Health, Neuherberg, Germany. ${ }^{4}$ Air Pollution Epidemiology Section, Office of Environmental Health Hazard Assessment, State of California, Oakland, CA, USA. ${ }^{5}$ Julius Center for Health Sciences and Primary Care, University Medical Center, Utrecht, The Netherlands.

Received: 19 December 2012 Accepted: 2 April 2013

Published: 28 May 2013

\section{References}

1. World Health Organization: Systematic review of air pollution, a global update. 2006.

2. Pope CA 3rd, Dockery DW: Health effects of fine particulate air pollution: lines that connect. J Air Waste Manag Assoc 2006, 56:709-742.

3. Brunekreef B, Holgate ST: Air pollution and health. Lancet 2002, 360:1233-1242.

4. Brook RD, Rajagopalan S, Pope CA, Brook JR, Bhatnagar A, Diez-Roux AV, Holguin F, Hong Y, Luepker RV, Mittleman MA, Peters A, Siscovick D, Smith SC, Whitsel L, Kaufman JD: Particulate matter air pollution and cardiovascular disease: an update to the scientific statement from the American heart association. Circulation 2010, 121:2331-2378.

5. Krishnan RM, Kaufman JD, Hoek G: Chronic effects of air pollution on cardiovascular health. In Cardiovascular effects of inhaled ultrafine and nanosized particles. Edited by Cassee FR, Mills NL, Newby D. Hoboken, New Jersey: John Wiley \& Sons, Inc; 2011.

6. HEl panel: Traffic-related air pollution. A critical review of the literature on emissions, exposure and health effects, HEl Special report 17. Boston, MA: Health Effects Institute; 2010.

7. Janssen NA, Hoek G, Simic-Lawson M, Fischer $P$, van Bree $L$, ten Brink $H$, Keuken M, Atkinson RW, Anderson HR, Brunekreef B, Cassee FR: Black carbon as an additional indicator of the adverse effects of airborne particles compared with PM10 and PM2.5. Environ Health Perspect 2011, 119:1691-1699. 
8. Peters A, Rückerl R, Cyrys J: Lessons from air pollution epidemiology for studies of engineered nanomaterials. J Occup Environ Med 2011, 53(6 SUPPL):S8-S13.

9. Rückerl R, Schneider A, Breitner S, Cyrys J, Peters A: Health effects of particulate air pollution: a review of epidemiological evidence. Inhal Toxicol 2011, 23:555-592.

10. Boogaard H, Kos GPA, Weijers EP, Janssen NAH, Fischer PH, van der Zee SC, de Hartog JJ, Hoek G: Contrast in air pollution components between major streets and background locations: particulate matter mass, black carbon, elemental composition, nitrogen oxide and ultrafine particle number. Atmos Environ 2011, 45:650-658.

11. Brunekreef $B$, Forsberg B: Epidemiological evidence of effects of coarse airborne particles on health. Eur Respir J 2005, 26:309-318.

12. DerSimonian R, Laird N: Meta-analysis in clinical trials. Control Clin Trials 177, 7:177-188.

13. Higgins JPT, Thompson SG, Deeks JJ, Altman DG: Measuring inconsistency in meta-analyses. Br Med J 2003, 327:557-560.

14. Laden F, Schwartz J, Speizer FE, Dockery DW: Reduction in fine particulate Air pollution and mortality: extended follow-up of the Harvard Six cities study. Am J Respir Crit Care Med 2006, 173:667-672.

15. Dockery DW, Pope CA III, Xu X, Spengler JD, Ware JH, Fay ME, Ferris BG Jr, Speizer FE: An association between air pollution and mortality in six U.S. cities. N Engl J Med 1993, 329:1753-1759.

16. Lepeule J, Laden F, Dockery D, Schwartz J: Chronic exposure to fine particles and mortality: an extended follow-up of the Harvard six cities study from 1974 to 2009. Environ Health Perspect 2012, 120:965-970.

17. Pope CA 3rd, Thun MJ, Namboodiri MM, Dockery DW, Evans JS, Speizer FE, Jr HC: Particulate air pollution as a predictor of mortality in a prospective study of U.S. adults. Am J Respir Crit Care Med 1995, 151:669-674.

18. Pope CA 3rd, Thun MJ, Calle EE, Krewski D, Ito K, Thurston GD: Lung cancer, cardiopulmonary mortality, and long-term exposure to fine particulate air pollution. JAMA 2002, 287:1132-1141.

19. Jerrett M, Burnett RT, Ma R, Pope CA 3rd, Krewski D, Newbold KB, Thurston $G$, Shi Y, Finkelstein N, Calle EE, Thun MJ: Spatial analysis of air pollution and mortality in Los Angeles. Epidemiology 2005, 16:727-736.

20. Gehring U, Heinrich J, Kramer U, Grote V, Hochadel M, Sugiri D, Kraft M, Rauchfuss K, Eberwein HG, Wichmann HE: Long-term exposure to ambient air pollution and cardiopulmonary mortality in women. Epidemiology 2006, 17:545-551.

21. Heinrich J, Thiering E, Rzehak P, Krämer U, Hochadel M, Rauchfuss KM, Gehring U, Wichmann H: Long-term exposure to NO2 and PM10 and all-cause and cause-specific mortality in a prospective cohort of women. Occup Environ Med 2013, 70:179-186.

22. Miller KA, Siscovick DS, Sheppard L, Shepherd K, Sullivan JH, Anderson GL, Kaufman JD: Long-term exposure to air pollution and incidence of cardiovascular events in women. N Engl J Med 2007, 356:447-458.

23. Beelen $R$, Hoek $G$, van den Brandt PA, Goldbohm RA, Fischer P, Schouten LJ, Jerrett $M$, Hughes $E$, Armstrong B, Brunekreef B: Long-term effects of traffic-related air pollution on mortality in a Dutch cohort (NLCS-AIR study). Environ Health Perspect 2008, 116:196-202.

24. Puett RC, Schwartz J, Hart JE, Yanosky JD, Speizer FE, Suh H, Paciorek CJ, Neas LM, Laden F: Chronic particulate exposure, mortality, and coronary heart disease in the Nurses' Health Study. Am J Epidemiol 2008, 168:1161-1168.

25. Puett RC, Hart JE, Yanosky JD, Paciorek C, Schwartz J, Suh H, Speizer FE, Laden F: Chronic fine and coarse particulate exposure, mortality, and coronary heart disease in the Nurses' Health Study. Environ Health Perspect 2009, 117:1697-1701.

26. Zeger SL, Dominici F, McDermott A, Samet JM: Mortality in the Medicare population and chronic exposure to fine particulate air pollution in urban centers (2000-2005). Environ Health Perspect 2008, 116:1614-1619.

27. Ostro B, Lipsett M, Reynolds P, Goldberg D, Hertz A, Garcia C, Henderson $K D$, Bernstein L: Long-term exposure to constituents of fine particulate air pollution and mortality: results from the California teachers study. Environ Health Perspect 2010, 118:363-369.

28. Huss A, Spoerri A, Egger M, Röösli M: Aircraft noise, air pollution, and mortality from myocardial infarction. Epidemiology 2010, 21:829-836.

29. Puett RC, Hart JE, Suh H, Mittleman M, Laden F: Particulate matter exposures, mortality, and cardiovascular disease in the health professionals follow-up study. Environ Health Perspect 2011, 119:1130-1135.
30. Gan WQ, Koehoorn M, Davies HW, Demers PA, Tamburic L, Brauer M: Longterm exposure to traffic-related air pollution and the risk of coronary heart disease hospitalization and mortality. Environ Health Perspect 2011, 119:501-507.

31. Cao J, Yang C, Li J, Chen R, Chen B, Gu D, Kan H: Association between long-term exposure to outdoor air pollution and mortality in China: a cohort study. J Hazard Mater 2011, 186:1594-1600

32. Hart JE, Garshick E, Dockery DW, Smith TJ, Ryan L, Laden F: Long-term ambient multipollutant exposures and mortality. Am J Respir Crit Care Med 2011, 183:73-78.

33. Zhang P, Dong G, Sun B, Zhang L, Chen X, Ma N, Yu F, Guo H, Huang H, Lee $Y L$, Tang N, Chen J: Long-term exposure to ambient air pollution and mortality due to cardiovascular disease and cerebrovascular disease in Shenyang, China. PLoS One 2011, 6:e20827.

34. Crouse DL, Peters PA, van Donkelaar A, Goldberg MS, Villeneuve PJ, Brion O, Khan S, Atari DO, Jerrett M, Pope CA, Brauer M, Brook JR, Martin RV, Stieb D, Burnett RT: Risk of nonaccidental and cardiovascular mortality in relation to long-term exposure to low concentrations of fine particulate matter: a Canadian national-level cohort study. Environ Health Perspect 2012, 120:708-714.

35. Hales $\mathrm{S}$, Blakely $\mathrm{T}$, Woodward A: Air pollution and mortality in New Zealand: cohort study. J Epidemiol Community Health 2012, 66:468-473.

36. Lipsett MJ, Ostro BD, Reynolds P, Goldberg D, Hertz A, Jerrett M, Smith DF, Garcia C, Chang ET, Bernstein L: Long-term exposure to air pollution and cardiorespiratory disease in the California teachers study cohort. Am J Respir Crit Care Med 2011, 184:828-835.

37. Ueda K, Nagasawa SY, Nitta H, Miura K, Ueshima H, NIPPON DATA80 Research Group: Exposure to particulate matter and long-term risk of cardiovascular mortality in Japan: NIPPON DATA80. J Atheroscler Thromb 2012, 19:246-254

38. Cesaroni G, Badaloni C, Gariazzo C, Stafoggia M, Sozzi R, Davoli M, Forastiere F: Long-term exposure to urban air pollution and mortality in a cohort of more than a million adults in Rome. Environ Health Perspect 2013, 121:324-331.

39. Pope CA 3rd, Burnett RT, Thurston GD, Thun MJ, Calle EE, Krewski D, Godleski JJ: Cardiovascular mortality and long-term exposure to particulate air pollution: epidemiological evidence of general pathophysiological pathways of disease. Circulation 2004, 109:71-77.

40. Abbey DE, Nishino N, McDonnell WF, Burchette RJ, Knutsen SF, Lawrence BW Yang JX: Long-term inhalable particles and other air pollutants related to mortality in nonsmokers. Am J Respir Crit Care Med 1999, 159:373-382.

41. Chen LH, Knutsen SF, Shavlik D, Beeson WL, Petersen F, Ghamsary M, Abbey $D$ : The association between fatal coronary heart disease and ambient particulate air pollution: Are females at greater risk? Environ Health Perspect 2005, 113:1723-1729.

42. Filleul L, Rondeau V, Vandentorren S, Le Moual N, Cantagrel A, AnnesiMaesano I, Charpin D, Declerca C, Neukirch F, Paris C, Vervloet D, Brochard $P$, Tessier JF, Kauffmann F, Baldi I: Twenty five year mortality and air pollution: results from the French PAARC survey. Occup Environ Med 2005, 62:453-460

43. Krewski D, Jerrett M, Burnett RT, Ma R, Hughes E, Shi Y, Turner MC, Pope CA Thurston G, Calle EE, Thun MJ, Beckerman B, DeLuca P, Finkelstein N, Ito K, Moore DK, Newbold KB, Ramsay T, Ross Z, Shin H, Tempalski B: Extended follow-up and spatial analysis of the American cancer society study linking particulate air pollution and mortality. Res Rep Health Eff Inst 2009, 140:5-114. discussion 115-36.

44. Ljungman $P$, Bellander $T$, Schneider A, Breitner S, Forastiera F, Hampel R, Illig T, Jacquemin B, Katsouyanni K, von Klot S, Koenig W, Lanki T, Nyberg F, Pekkanen J, Pistelli R, Pitsavos C, Rosenqvist M, Sunyer J, Peters A: Modification of the interleukin- 6 response to air pollution by interleukin- 6 and fibrinogen polymorphisms. Environ Health Perspect 2009, 117:1373-1379.

45. Peters A, Greven S, Heid IM, Baldari F, Breitner S, Bellander T, Chrysohoou C, Illig T, Jacquemin B, Koenig W, Lanki T, Nyberg F, Pekkanen J, Pistelli R, Rückerl R, Stefanadis C, Schneider A, Sunyer J, Wichmann HE: Fibrinogen genes modify the fibrinogen response to ambient particulate matter. Am J Respir Crit Care Med 2009, 179:484-491.

46. Janssen NA, Schwartz J, Zanobetti A, Suh HH: Air conditioning and sourcespecific particles as modifiers of the effect of $\mathrm{PM}(10)$ on hospital admissions for heart and lung disease. Environ Health Perspect 2002, 110:43-49. 
47. Mercer LD, Szpiro AA, Sheppard L, Lindström J, Adar SD, Allen RW, Avol EL, Oron AP, Larson T, Liu L-S, Kaufman JD: Comparing universal kriging and land-use regression for predicting concentrations of gaseous oxides of nitrogen (NOx) for the Multi-Ethnic Study of Atherosclerosis and Air Pollution (MESA Air). Atmos Environ 2011, 45:4412-4420.

48. Cohen MA, Adar SD, Allen RW, Avol E, Curl CL, Gould T, Hardie D, Ho A, Kinney P, Larson TV, Sampson P, Sheppard L, Stukovsky KD, Swan SS, Liu L-S , Kaufman JD: Approach to estimating participant pollutant exposures in the Multi-Ethnic Study of Atherosclerosis and Air Pollution (MESA Air) Environ Sci Technol 2009, 43:4687-4693.

49. Van Roosbroeck S, Hoek G, Meliefste K, Janssen NA, Brunekreef B: Validity of residential traffic intensity as an estimate of long-term personal exposure to traffic-related air pollution among adults. Environ Sci Technol 2008, 42:1337-1344.

50. Katsouyanni K, Touloumi G, Samoli E, Gryparis A, Le Tertre A, Monopolis Y, Rossi G, Zmirou D, Ballester F, Boumghar A, Anderson HR, Wojtyniak B, Paldy A, Braunstein R, Pekkanen J, Schindler C, Schwartz J: Confounding and effect modification in the short-term effects of ambient particles on total mortality: results from 29 European cities within the APHEA2 project. Epidemiology 2001, 12:521-531.

51. Laden F, Neas LM, Dockery DW, Schwartz J: Association of fine particulate matter from different sources with daily mortality in six U.S. cities. Environ Health Perspect 2000, 108:941-947.

52. Lanki T, de Hartog J, Heinrich J, Hoek G, Janssen NA, Peters A, Stolzel M, Timonen KL, Vallius M, Vanninen E, Pekkanen J: Can we identify sources of fine particles responsible for exercise-induced ischemia on days with elevated air pollution? The ULTRA study. Environ Health Perspect 2006, 114:655-660.

53. Bell ML, Ebisu K, Peng RD, Samet JM, Dominici F: Hospital admissions and chemical composition of fine particle air pollution. Am J Respir Crit Care Med 2009, 179:1115-1120.

54. Zanobetti A, Bind MA, Schwartz J: Particulate air pollution and survival in a COPD cohort. Environ Health 2008, 7:48.

55. Zanobetti A, Schwartz J: Particulate air pollution, progression, and survival after myocardial infarction. Environ Health Perspect 2007, 115:769-775.

56. Cesaroni G, Porta D, Badaloni C, Stafoggia M, Eeftens M, Meliefste K, Forastiere F: Nitrogen dioxide levels estimated from land use regression models several years apart and association with mortality in a large cohort study. Environ Health 2012, 11:48.

57. Eeftens M, Beelen R, Fischer P, Brunekreef B, Meliefste K, Hoek G: Stability of measured and modelled spatial contrasts in NO2 over time. Occup Environ Med 2011, 68:765-770.

58. Wang R, Henderson SB, Sbihi H, Allen RW, Brauer M: Temporal stability of land use regression models for traffic-related air pollution. Atmos Environ 2013, 64:312-319.

59. Dong GH, Zhang $P$, Sun $B$, Zhang $L$, Chen $X$, Ma N, Yu F, Guo H, Huang $H$, Lee $Y L$, Tang N, Chen J: Long-term exposure to ambient air pollution and respiratory disease mortality in Shenyang, China: a 12-year population-based retrospective cohort study. Respiration 2012, 84:360-368

60. Beelen R, Hoek G, Houthuijs D, van den Brandt PA, Goldbohm RA, Fischer P, Schouten $\amalg$, Armstrong B, Brunekreef B: The joint association of air pollution and noise from road traffic with cardiovascular mortality in a cohort study. Occup Environ Med 2009, 66:243-250.

61. Selander J, Nilsson ME, Bluhm G, Rosenlund M, Lindqvist M, Nise G, Pershagen G: Long-term exposure to road traffic noise and myocardial infarction. Epidemiology 2009, 20:272-279.

62. Gan WQ, Davies HW, Koehoorn M, Brauer M: Association of long-term exposure to community noise and traffic-related air pollution with coronary heart disease mortality. Am J Epidemio/ 2012, 175:898-906.

63. McDonnell WF, Nishino-Ishikawa N, Petersen FF, Chen LH, Abbey DE Relationships of mortality with the fine and coarse fractions of longterm ambient PM10 concentrations in nonsmokers. J Expo Anal Environ Epidemiol 2000, 10:427-436.

64. Smith $K R$, Jerrett $M$, Anderson HR, Burnett RT, Stone $V$, Derwent $R$, Atkinson RW, Cohen A, Shonkoff SB, Krewski D, Pope CA 3rd, Thun MJ, Thurston G: Public health benefits of strategies to reduce greenhouse-gas emissions: health implications of short-lived greenhouse pollutants. Lancet 2009, 374:2091-2103.

65. von Klot S, Gryparis A, Tonne C, Yanosky J, Coull BA, Goldberg RJ, Lessard D, Melly SJ, Suh $\mathrm{HH}$, Schwartz J: Elemental carbon exposure at residence and survival after acute myocardial infarction. Epidemiology 2009, 20:547-554.
66. Lipfert F, Wyzga R, Baty J, Miller J: Traffic density as a surrogate measure of environmental exposures in studies of air pollution health effects: long-term mortality in a cohort of US veterans. Atmos Environ 2006, 40:154-169.

67. Beverland IJ, Cohen GR, Heal MR, Carder M, Yap C, Robertson C, Hart CL, Agius RM: A comparison of short-term and long-term air pollution exposure associations with mortality in two cohorts in Scotland. Environ Health Perspect 2012, 120:1280-1285.

68. Nafstad P, Haheim LL, Wisloff T, Gram F, Oftedal B, Holme I, Hjermann I, Leren P: Urban air pollution and mortality in a cohort of Norwegian men. Environ Health Perspect 2004, 112:610-615.

69. Raaschou-Nielsen O, Andersen ZJ, Jensen SS, Ketzel M, Sorensen M, Hansen J, Loft S, Tjonneland A, Overvad K: Traffic air pollution and mortality from cardiovascular disease and all causes: a Danish cohort study. Environ Health 2012, 11:60.

70. Yorifuji T, Kashima S, Tsuda T, Takao S, Suzuki E, Doi H, Sugiyama M, Ishikawa-Takata K, Ohta T: Long-term exposure to traffic-related air pollution and mortality in Shizuoka, Japan. Occup Environ Med 2010, 67:111-117.

71. Chen H, Goldberg MS, Burnett RT, Jerrett M, Wheeler AJ, Villeneuve PJ: Long-term exposure to traffic-related air pollution and cardiovascular mortality. Epidemiology 2013, 24:35-43.

72. Rosenlund M, Berglind N, Pershagen G, Hallqvist J, Jonson T, Bellander T: Long-term exposure to urban air pollution and myocardial infarction. Epidemiology 2006, 17:383-390

73. Rosenlund M, Picciotto S, Forastiere F, Stafoggia M, Perucci CA: Trafficrelated air pollution in relation to incidence and prognosis of coronary heart disease. Epidemiology 2008, 19:121-128.

74. Rosenlund M, Bellander T, Nordquist T, Alfredsson L: Traffic-generated air pollution and myocardial infarction. Epidemiology 2009, 20:265-271.

75. Heckbert SR, Kooperberg C, Safford MM, Psaty BM, Hsia J, McTiernan A, Gaziano JM, Frishman WH, Curb JD: Comparison of self-report, hospital discharge codes, and adjudication of cardiovascular events in the Women's Health Initiative. Am J Epidemiol 2004, 160:1152-1158.

76. Mills NL, Donaldson K, Hadoke PW, Boon NA, MacNee W, Cassee FR, Sandstrom T, Blomberg A, Newby DE: Adverse cardiovascular effects of air pollution. Nat Clin Pract Cardiovasc Med 2009, 6:36-44.

77. Kunzli N, Jerrett M, Mack WJ, Beckerman B, LaBree L, Gilliland F, Thomas D, Peters J, Hodis HN: Ambient air pollution and atherosclerosis in Los Angeles. Environ Health Perspect 2005, 113:201-206.

78. Maheswaran R, Elliott P: Stroke mortality associated with living near main roads in England and Wales: a geographical study. Stroke 2003, 34:2776-2780.

79. Maheswaran R, Haining RP, Pearson T, Law J, Brindley P, Best NG: Outdoor NOx and stroke mortality: adjusting for small area level smoking prevalence using a Bayesian approach. Stat Methods Med Res 2006, 15:499-516.

80. Ljungman PL, Berglind N, Holmgren C, Gadler F, Edvardsson N, Pershagen G, Rosenqvist M, Sjögren B, Bellander T: Rapid effects of air pollution on ventricular arrhythmias. Eur Heart J 2008, 29:2894-2901.

\section{doi:10.1186/1476-069X-12-43}

Cite this article as: Hoek et al.: Long-term air pollution exposure and cardio- respiratory mortality: a review. Environmental Health 2013 12:43.

\section{Submit your next manuscript to BioMed Central and take full advantage of:}

- Convenient online submission

- Thorough peer review

- No space constraints or color figure charges

- Immediate publication on acceptance

- Inclusion in PubMed, CAS, Scopus and Google Scholar

- Research which is freely available for redistribution 